\title{
Bromine Uptake of Muskmelon and Cucumber Plants Following Soil Fumigation with Methyl Bromide
}

\author{
Masao Masui, Akira Nukaya, Takayasu Ogura \\ and Akira IsHida \\ College of Agriculture, Shizuoka University, Ohya, Shizuoka
}

\begin{abstract}
Summary
Muskmelons and cucumbers were grown in soil fumigated with methyl bromide $(\mathrm{MBr})$ to determine the effect of $\mathrm{MBr}$ on the growth, bromine ( $\mathrm{Br}$ ) content in the plant and the content of water soluble $\mathrm{Br}$ in the soil. The dry weight of the whole muskmelon plant was less at $600 \mathrm{~g} / \mathrm{m}^{3} \mathrm{MBr}$, while soluble solids of fruit were slightly higher at this dosage. Br content in muskmelon leaves at 0, 200, 400 and $600 \mathrm{~g} / \mathrm{m}^{3} \mathrm{MBr}$ soil treatments was 203, 540, 3663 and $6783 \mathrm{ppm}$, respectively. $\mathrm{Br}$ in the musk melon fruit was most concentrated in the pericarp, less concentrated in the outer flesh, and least concentrated in the inner flesh. On a dry matter basis $\mathrm{Br}$ content in the inner and outer flesh at $0,200,400$ and $600 \mathrm{~g} / \mathrm{m}^{3} \mathrm{MBr}$ treatments was as follows: the inner flesh was 47, 24, 109 and $228 \mathrm{ppm}$; the outer flesh was $60,154,137$ and $323 \mathrm{ppm}$, respectively. Growth and yield of cucumbers grown in Iwata loam (IL) having $13.3 \%$ clay were not affected by dosage levels of $\mathrm{MBr}$. Br content in the leaves, roots and fruit was significantly increased with increasing amounts of $\mathrm{MBr}$. Growth and yield of cucumbers grown in Takamatsu light clay (TLiC) having $35.8 \%$ clay were not affected by dosage levels of $\mathrm{MBr}$. On a dry matter basis $\mathrm{Br}$ content in leaves, roots and fruit was markedly higher in TLiC than in IL, and that in fruit at $0,200,400$ and $800 \mathrm{~g} / \mathrm{m}^{3} \mathrm{MBr}$ was 202 to 240,590 to 900,1080 to 1742 , and 1750 to $2788 \mathrm{ppm}$, respectively. Uptake amount of $\mathrm{Br}$ by cucumber plants was significantly increased with time at all dosage levels of $\mathrm{MBr}$, while water soluble $\mathrm{Br}$ in soil was inversely decreased.
\end{abstract}

\section{Introduction}

Methyl bromide $(\mathrm{MBr})$ has been used by greenhouse growers to a great extent instead of steam sterilization. The reason for this is its easy application, its high toxicity to soilborne diseases such as fusarium wilt of tomato, cucumber and muskmelon, bacterial wilt of tomato and eggplant, and Phytophthora and Pythium, and its rapid and extensive penetration into soil. However, this fumigant posseses certain disadvantages, principally its high human toxicity, necessitating considerable care in its use, and its breakdown in soil to inorganic bromide $(\mathrm{Br})$ which is also toxic to some plants and can be taken up and accumulated in many crops. As to the intake of the $\mathrm{Br}$ ion, a joint $\mathrm{FAO} / \mathrm{WHO}$ working pa ty recommended in 1969 a maximum acceptable daily intake of 1 $\mathrm{mg} \mathrm{Br}$ ion per $\mathrm{Kg}$ body weight, with a toler-

\footnotetext{
Received for publication November 15, 1977
}

ance level of $50 \mathrm{mg}$ per $\mathrm{Kg}$ in raw cereals or whole meal flour (3). Aside from this recommendation the Food and Drug Administration (FDA) of the Department of Health, Education and Welfare, and the Environment Protection Agency in the U.S.A. established a tolerance level of $\mathrm{Br}$ ion in many crops in 1972 $(14,15,16)$. In our country little is found about the $\mathrm{Br}$ residues in vegetable crops grown in soil fumigated with $\mathrm{Br}$ containing compounds. We have been concerned with the growth and uptake of inorganic $\mathrm{Br}$ in several vegetable crops grown in soil fumigated with $\mathrm{MBr}$. This paper deals with the results of $\mathrm{Br}$ uptake of muskmelons and cucumbers.

\section{Materials and Methods}

\section{Muskmelons}

Some greenhouse growers sterilize soil beds with $\mathrm{MBr}$ using 2 or 3 times the amount recommended by the fumigant dealers. There- 
fore, 4 dosage levels of $\mathrm{MBr}$ were made as follows: $0 \mathrm{~g} / \mathrm{m}^{3}$ (not fumigated, $0 \mathrm{~S}$ for short), $200 \mathrm{~g} / \mathrm{m}^{3}$ (standard, $1 \mathrm{~S}$ ), $400 \mathrm{~g} / \mathrm{m}^{3}(2 \mathrm{~S}$ ) and $600 \mathrm{~g} / \mathrm{m}^{3}(3 \mathrm{~S})$. The corresponding amount of $\mathrm{MBr}$ of each dosage was released from a canister into the soil under a vinylfilm cover continuously for 4 days. The soil used was Iwata loam and originally had a $\mathrm{pH}$ of 5.8 and $2.2 \mathrm{ppm}$ of water soluble $\mathrm{Br}$. After removing the cover, fumigated soils were well tilled to evaporate the residual fumigant.

Sixteen liters of fumigated soil were fertilized with $7 \mathrm{~g} \mathrm{~N}$ from rape-seed cake, $10 \mathrm{~g} \mathrm{P}_{2} \mathrm{O}_{5}$ from calcium superphosphate and rape-seed cake, $10 \mathrm{~g} \mathrm{~K}_{2} \mathrm{O}$ from $\mathrm{K}_{2} \mathrm{SO}_{4}$ and rape-seed cake, $20 \mathrm{~g} \mathrm{CaO}$ from $\mathrm{Ca}(\mathrm{OH})_{2}$ and 8 liters of well decomposed rice straw, and put into a $40 \times 40 \times 20 \mathrm{~cm}$ box. Seedlings with 3 leaves of muskmelon cv. Spring No. 3 of Earl's Favourite grafted on Barnett Hill Favourite rootstock were planted in boxes filled with the fumigated soils, on May 7, 1974, and grown under uniform conditions in the greenhouse. The treatments were replicated 12 times. The plants were separated into leaves, stems, roots and fruit at harvest, and the fruit was further sectioned as shown in Fig.

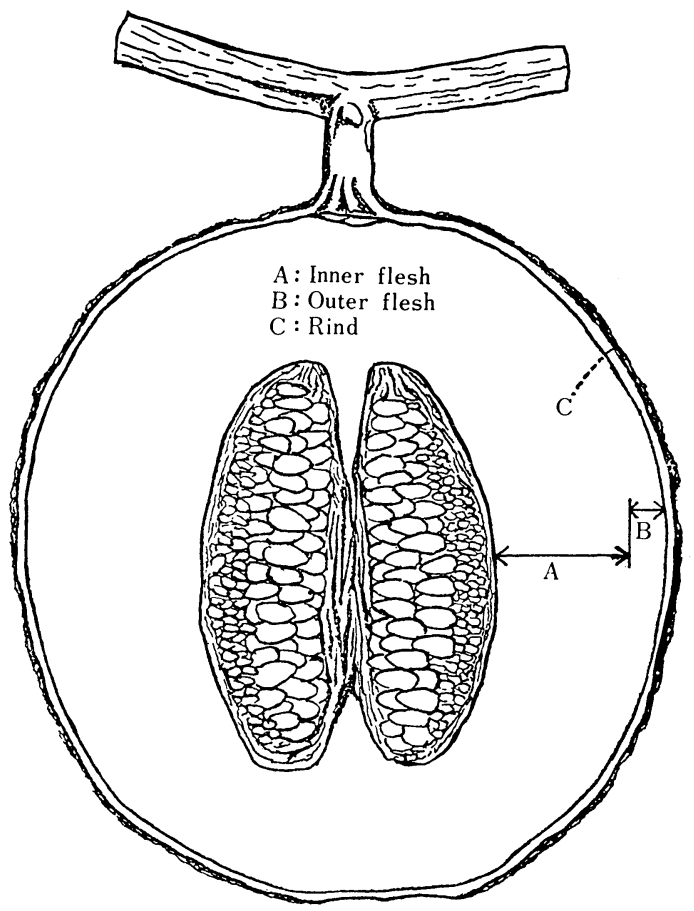

Fig. 1. Cross section of muskmenlon fruit.
1. The materials were dried at $70^{\circ} \mathrm{C}$ and finely milled. Mixed $1 \mathrm{~g}$ samples with $250 \mathrm{mg}$ $\mathrm{CaO}$ in sufficient water to give a thin paste were ashed at $550^{\circ} \mathrm{C}$ overnight and the residues extracted with hot water. The whole extract was adjusted to $\mathrm{pH} 6.5 \sim 7.0$ with $\mathrm{HNO}_{3}$ or $\mathrm{NaOH}$ and filled up to $100 \mathrm{ml}$. An aliquot of this extract was colorimetrically determined by the fluorescein method (12). Soils for analysis taken at harvest were air dried and milled to pass through a $2 \mathrm{~mm}$ sieve. Water soluble $\mathrm{Br}$ was determined by the same method as used for plant materials after extracting $10 \mathrm{~g}$ of soil with $50 \mathrm{ml}$ water and adjusting the soil extract to $\mathrm{pH} 6.0$ with $\mathrm{H}_{2} \mathrm{SO}_{4}$ or $\mathrm{NaOH}$.

\section{Cucumbers}

Expt. I

To determine the effects of soil fumigation with $\mathrm{MBr}$ on the growth and $\mathrm{Br}$ uptake of cucumbers, the treatment of 4 dosage levels of $\mathrm{MBr}, 0 \mathrm{~g} / \mathrm{m}^{3}$ (not fumigated, $0 \mathrm{~S}$ ), $100 \mathrm{~g} / \mathrm{m}^{3}$ (0.5S), $200 \mathrm{~g} / \mathrm{m}^{3}$ (standard, $1 \mathrm{~S}$ ) and $400 \mathrm{~g} / \mathrm{m}^{3}$ (2S), was made in 7 replications. The soil was the same as used in the muskmelon experiment, and was fumigated with $\mathrm{MBr}$ by the same method as in the muskmelon experiment. Sixteen liters of fumigated soil was fertilized with $3 \mathrm{~g} \mathrm{~N}$ from $\left(\mathrm{NH}_{4}\right)_{2} \mathrm{SO}_{4}, 5 \mathrm{~g} \mathrm{P}_{2} \mathrm{O}_{5}$ from calcium superphosphate, $3.5 \mathrm{~g} \mathrm{~K}_{2} \mathrm{O}$ from $\mathrm{K}_{2}$ $\mathrm{SO}_{4}, 30 \mathrm{~g} \mathrm{CaO}$ from $\mathrm{Ca}(\mathrm{OH})_{2}$ and 8 liters of semi-decomposed rice straw, and put into a $40 \times 40 \times 20 \mathrm{~cm}$ box. One 3-leafed seedling of cucumber cv. Natsusairaku No. 3 was planted in each box filled with the fumigated soil on March 18, 1975, and grown in the greenhouse. The main stem was pinched at the 17 th node and lateral shoots from 6 th to 16 th node were pinched at the 1 st node. Fruits sized 70 to $100 \mathrm{~g}$ were picked April 14 through May 14. The fruits were sorted into early and late pickings as shown in Table 2. After all fruits were harvested, the leaves, stems and roots were separated, dried and milled. $\mathrm{Br}$ content of the plant and soil was determined by the same methods as in the muskmelon experiment.

Expt. II

The purpose was to determine the effects of soil fumigation with $\mathrm{MBr}$ on the $\mathrm{Br}$ uptake by cucumber plants in relation to their grow th 
and the $\mathrm{Br}$ content in soils during the course of the experiment. On Oct. 15, 1975 seedlings with 3 leaves of cucumbers cv. Natsusairaku No. 3 were planted in boxes filled with differentially fumigated soils, $0 \mathrm{~g} / \mathrm{m}^{3}(0 \mathrm{~S}), 200$ $\mathrm{g} / \mathrm{m}^{3}$ (standard, $1 \mathrm{~S}$ ), $400 \mathrm{~g} / \mathrm{m}^{3}(2 \mathrm{~S})$ and 800 $\mathrm{g} / \mathrm{m}^{3}(4 \mathrm{~S})$, and grown in the greenhouse. The soil used was Takamatsu light clay with an original $\mathrm{pH} 5.7$ and $6.0 \mathrm{ppm}$ water soluble Br. Cultivation and fertilization were similar to those in Expt. I with cucumbers. Plant samples of leaves, stems and roots were taken on Oct. 29, Nov. 14, Nov. 26 and Dec. 10. Fruits were picked when they weighed 70 to $100 \mathrm{~g}$ to determine the $\mathrm{Br}$ content. Soil samples were taken on Oct. 15, Oct. 29, Nov. 14, Nov. 26 and Dec. 10 to determine water soluble $\mathrm{Br}$.

\section{Results}

\section{Muskmelons}

The effects of soil fumigation with $\mathrm{MBr}$ on the growth and $\mathrm{Br}$ in plant parts of muskmelons, and on the water soluble $\mathrm{Br}$ in soil are shown in Table 1 . The early growth of plants tended to be restricted at $3 \mathrm{~S}$. However no significant difference in the plant height was found among the treatments at the end of the experiment. The dry weight of a whole plant was less at $3 \mathrm{~S}$. The fresh weight of fruit was also less at $3 \mathrm{~S}$, while the soluble solids of fruit were slightly higher at $3 \mathrm{~S}$. $\mathrm{Br}$ content in leaves and whole fruit was significantly increased with increasing amount of $\mathrm{MBr}$. Br content in the inner flesh, outer flesh and pericarp tended to increase with increasing amount of $\mathrm{MBr}$, and $\mathrm{Br}$ in fruit was generally most concentrated in the pericarp, less concentrated in the outer flesh, and least concentrated in the inner flesh. Water soluble $\mathrm{Br}$ was slightly higher at $3 \mathrm{~S}$. No chlorosis or necrosis of the leaves caused by $\mathrm{MBr}$ was found even at $3 \mathrm{~S}$.

\section{Cucumbers}

Expt. I

The effects of soil fumigation with $\mathrm{MBr}$ on the cucumber growth and water soluble $\mathrm{Br}$ in soil are given in Table 2. The number and weight of fruit per plant were not significantly different among the treatments. Growth was

Table 1. Effect of methyl bromide soil fumigation on growth and $\mathrm{Br}$ content of muskmelons and on soil $\mathrm{Br}$ content.

\begin{tabular}{|c|c|c|c|c|c|c|c|c|c|c|}
\hline \multirow[b]{2}{*}{ Treatment } & \multirow{2}{*}{$\begin{array}{l}\text { Plant ht }{ }^{\mathrm{w}} \\
\text { at the end } \\
\text { of expt. } \\
(\mathrm{cm})\end{array}$} & \multirow{2}{*}{$\begin{array}{l}\text { Dry wt } \mathrm{t}^{\mathrm{x}} \\
\text { of whole } \\
\text { plant } \\
\qquad(\mathrm{g})\end{array}$} & \multirow{2}{*}{$\begin{array}{l}\text { Fruit } \\
\text { fresh } \\
\text { wt } \\
(\mathrm{g})\end{array}$} & \multirow{2}{*}{$\begin{array}{l}\text { Soluble } \\
\text { solids } \\
\text { of fruit } \\
\quad(\%)\end{array}$} & \multicolumn{6}{|c|}{$\mathrm{Br}$ in plant dry matter and in air dried soil (ppm) } \\
\hline & & & & & Leaves & $\begin{array}{l}\text { Whole } \\
\text { fruit }\end{array}$ & $\begin{array}{l}\text { Inner } \\
\text { flesh }\end{array}$ & $\begin{array}{l}\text { OuterY } \\
\text { flesh }\end{array}$ & $\operatorname{Rind}^{\mathrm{Y}}$ & $\begin{array}{l}\text { Soil at } \\
\text { the end } \\
\text { of expt. }\end{array}$ \\
\hline $0 \mathrm{~S}$ & $105^{\mathrm{a}}$ & $248^{\mathrm{a}}$ & $1271^{\mathrm{a}}$ & $12.5^{\mathrm{b}}$ & $203^{c}$ & $164^{\mathrm{c}}$ & 47 & 60 & 89 & $7.2^{\mathrm{b}}$ \\
\hline $1 \mathrm{~S}$ & $105^{\mathrm{a}}$ & $259^{a}$ & $1303^{a}$ & $12.2^{\mathrm{b}}$ & $540^{c}$ & $303^{c}$ & 24 & 154 & 467 & $8.6^{\mathrm{ab}}$ \\
\hline $2 \mathrm{~S}$ & $105^{\mathrm{a}}$ & $254^{\mathrm{a}}$ & $1259^{\mathrm{a}}$ & $12.2^{\mathrm{b}}$ & $3663^{b}$ & $652^{\mathrm{b}}$ & 109 & 137 & 1110 & $7.4^{\mathrm{b}}$ \\
\hline $3 \mathrm{~S}$ & $101^{\mathrm{a}}$ & $234^{\mathrm{b}}$ & $1162^{\mathrm{b}}$ & $13.5^{\mathrm{a}}$ & $6783^{a}$ & $987^{a}$ & 223 & 323 & 1215 & $9.3^{a}$ \\
\hline
\end{tabular}

W : Mean separation in columns by Duncan's multiple range test, $5 \%$ level.

$\mathrm{X}$ : Leaves + Stems + Roots + fruit.

$\mathrm{Y}:$ Not subjected to statistical analysis because composite materials were taken.

Table 2. Effect of methyl bromide soil fumigation on growth and $\mathrm{Br}$ content of cucumbers and on soil Br content.

\begin{tabular}{|c|c|c|c|c|c|c|c|c|c|c|}
\hline \multirow[b]{2}{*}{ Treatment } & \multirow[b]{2}{*}{$\begin{array}{l}\text { No. of } \\
\text { fruit/ } \\
\text { plant }\end{array}$} & \multirow[b]{2}{*}{$\begin{array}{l}\text { Fruit } \\
\text { fresh wt/ } \\
\text { plant } \\
\text { (g) }\end{array}$} & \multicolumn{8}{|c|}{$\mathrm{Br}$ in plant dry matter and in air dried soil (ppm) } \\
\hline & & & Leaves & Roots & $\begin{array}{l}\text { Earlyw } \\
\text { picked } \\
\text { fruit on } \\
\text { main stem }\end{array}$ & $\begin{array}{l}\text { Late }^{\mathrm{x}} \\
\text { picked } \\
\text { fruit on } \\
\text { main stem }\end{array}$ & $\begin{array}{l}\text { Early } y \\
\text { picked } \\
\text { fruit on } \\
\text { lateral } \\
\text { shoots }\end{array}$ & $\begin{array}{l}\text { Late }^{z} \\
\text { picked } \\
\text { fruit on } \\
\text { lateral } \\
\text { shoots }\end{array}$ & $\begin{array}{l}\text { Soil just } \\
\text { after } \\
\text { fumiga- } \\
\text { tion }\end{array}$ & $\begin{array}{l}\text { Soil at } \\
\text { the end } \\
\text { of expt. }\end{array}$ \\
\hline $0 \mathrm{~S}$ & $18.4^{\mathrm{a}}$ & $1450^{\mathrm{a}}$ & $63^{\mathrm{b}}$ & $41^{\mathrm{c}}$ & $64^{\mathrm{c}}$ & $67^{\mathrm{c}}$ & $73^{c}$ & $85^{c}$ & $2.5^{\mathrm{c}}$ & $5.4^{\mathrm{a}}$ \\
\hline $0.5 \mathrm{~S}$ & $19.7^{\mathrm{a}}$ & $1490^{\mathrm{a}}$ & $78^{\mathrm{b}}$ & $49^{c}$ & $79^{\mathrm{bc}}$ & $97^{\mathrm{b}}$ & $91^{\mathrm{bc}}$ & $98^{c}$ & $3.9^{b c}$ & $5.1^{\mathrm{a}}$ \\
\hline $1 \mathrm{~S}$ & $19.7^{\mathrm{a}}$ & $1594^{a}$ & $110^{\mathrm{b}}$ & $120^{\mathrm{b}}$ & $91^{\mathrm{b}}$ & $98^{b}$ & $106^{\mathrm{b}}$ & $153^{b}$ & $5.5^{\mathrm{b}}$ & $5.7^{\mathrm{a}}$ \\
\hline $2 \mathrm{~S}$ & $21.1^{\mathrm{a}}$ & $1569^{\mathrm{a}}$ & $180^{\mathrm{a}}$ & $241^{\mathrm{a}}$ & $131^{\mathrm{a}}$ & $189^{\mathrm{a}}$ & $197^{\mathrm{a}}$ & $246^{\mathrm{a}}$ & $11.6^{\mathrm{a}}$ & $5.5^{\mathrm{a}}$ \\
\hline
\end{tabular}

$\mathrm{V}:$ Mean separation in columns by Duncan's multiple range test, $5 \%$ level.

W : Apr. 14 to Apr. 24, X:Apr. 25 to May 6, Y:Apr. 24 to May 3, Z: May 4 to May 14. 
not influenced by $\mathrm{MBr}$ levels although results are not shown. Br content in the fruit was significantly increased with increasing amounts of $\mathrm{MBr} . \mathrm{Br}$ content tended to be slightly higher in the late picked and lateral shoot fruit than in the early picked and main stem fruit, respectively. The soil water soluble
$\mathrm{Br}$ just after $\mathrm{MBr}$ fumigation was significantly increased with increasing amounts of $\mathrm{MBr}$. However, the $\mathrm{Br}$ content at the end of the experiment was not significantly different among the treatments.

Expt. II

The effects of soil fumigation with $\mathrm{MBr}$ on

Table 3. Effect of methyl bromide soil fumigtion on growth and $\mathrm{Br}$ uptake of the cucumber plant.

\begin{tabular}{|c|c|c|c|c|c|c|c|c|}
\hline \multirow[b]{2}{*}{ Treatment } & \multirow{2}{*}{$\begin{array}{l}\text { Plant ht }{ }^{v} \\
\text { pinched at } \\
17 \text { th node } \\
(\mathrm{cm})\end{array}$} & \multirow{2}{*}{$\begin{array}{c}\text { Leaves } \\
\text { dry } w t / \text { plant } \\
(\mathrm{g})\end{array}$} & \multirow{2}{*}{$\begin{array}{c}\text { Stems } \\
\text { dry wt/plant } \\
(\mathrm{g})\end{array}$} & \multirow{2}{*}{$\mid \begin{array}{c}\text { Fruit } \\
\text { fresh wt/plant } \\
(\mathrm{g})\end{array}$} & \multicolumn{4}{|c|}{ Amounts of $\mathrm{Br}$ uptake (mg/plant) ${ }^{\mathrm{w}}$} \\
\hline & & & & & Oct. 29 & Nov. 14 & Nov. 26 & Dec. 10 \\
\hline $0 \mathrm{~S}$ & $162^{\mathrm{a}}$ & $41.8^{a}$ & $19.9^{a}$ & $683^{\mathrm{a}}$ & $4^{\mathrm{c}}$ & $15^{\mathrm{c}}$ & $21^{d}$ & $60^{\mathrm{d}}$ \\
\hline $1 \mathrm{~S}$ & $152^{\mathrm{a}}$ & $42.5^{a}$ & $20.0^{a}$ & $760^{\mathrm{a}}$ & $24^{\mathrm{b}}$ & $36^{c}$ & $99^{c}$ & $159^{\mathrm{c}}$ \\
\hline $2 \mathrm{~S}$ & $153^{\mathrm{a}}$ & $41.5^{a}$ & $20.7^{\mathrm{a}}$ & $729^{\mathbf{a}}$ & $51^{a}$ & $62^{\mathrm{b}}$ & $202^{b}$ & $244^{\mathrm{b}}$ \\
\hline $4 \mathrm{~S}$ & $158^{\mathrm{a}}$ & $46.5^{\mathrm{a}}$ & $21.5^{\mathrm{a}}$ & $747^{\mathrm{a}}$ & $62^{a}$ & $178^{\mathrm{a}}$ & $355^{\mathrm{a}}$ & $523^{a}$ \\
\hline
\end{tabular}

$\mathrm{V}$ : Mean separation in columns by Duncan's multiple range test, $5 \%$ level.

$\mathrm{W}:$ Whole plant $=$ Leaves + Stems + Roots + Fruit.

Table 4. Effect of methyl bromide soil fumigation on $\mathrm{Br}$ content in leaves and stems of cucumbers (ppm of dry matter).

\begin{tabular}{c|c|c|c|r|r|r|r|r|r}
\hline \multirow{2}{*}{ Treatment } & \multicolumn{3}{|c}{ Leaves $^{\mathrm{v}}$} & \multicolumn{4}{c}{ Stems } \\
\cline { 2 - 9 } & Oct. 29 & Nov. 14 & Nov. 26 & Dec. 10 & Oct. 29 & Nov. 14 & Nov. 26 & Dec. 10 \\
\hline $0 \mathrm{~S}$ & $718^{\mathrm{c}}$ & $553^{\mathrm{c}}$ & $369^{\mathrm{d}}$ & $931^{\mathrm{c}}$ & $768^{\mathrm{c}}$ & $241^{\mathrm{d}}$ & $420^{\mathrm{d}}$ & $465^{\mathrm{d}}$ \\
$1 \mathrm{~S}$ & $2533^{\mathrm{bc}}$ & $689^{\mathrm{bc}}$ & $831^{\mathrm{c}}$ & $2211^{\mathrm{b}}$ & $13280^{\mathrm{b}}$ & $3103^{\mathrm{c}}$ & $4890^{\mathrm{c}}$ & $2868^{\mathrm{c}}$ \\
$2 \mathrm{~S}$ & $4468^{\mathrm{ab}}$ & $1268^{\mathrm{b}}$ & $1533^{\mathrm{b}}$ & $2146^{\mathrm{b}}$ & $20730^{\mathrm{a}}$ & $5515^{\mathrm{b}}$ & $9905^{\mathrm{b}}$ & $4915^{\mathrm{b}}$ \\
$4 \mathrm{~S}$ & $5815^{\mathrm{a}}$ & $2971^{\mathrm{a}}$ & $2790^{\mathrm{a}}$ & $3638^{\mathrm{a}}$ & $20590^{\mathrm{a}}$ & $15825^{\mathrm{a}}$ & $17463^{\mathrm{a}}$ & $13288^{\mathrm{a}}$ \\
\hline
\end{tabular}

$\mathrm{V}$ : Mean separation in columns by Duncan's multiple range test, $5 \%$ level.

Table 5. Effect of methyl bromide soil fumigation on $\mathrm{Br}$ content in roots and fruit of cucumbers (ppm of dry matter).

\begin{tabular}{|c|c|c|c|c|c|c|c|c|}
\hline \multirow[b]{2}{*}{ Treatment } & \multirow[b]{2}{*}{ Oct. 29} & \multicolumn{3}{|c|}{ Roots $^{\mathrm{v}}$} & \multicolumn{4}{|c|}{ Fruit } \\
\hline & & Nov. 14 & Nov. 26 & Dec. 10 & $\begin{array}{l}\text { up to }{ }^{\mathrm{w}} \\
\text { Nov. } 14\end{array}$ & $\begin{array}{l}\text { Nov. } 15^{\mathrm{w}} \\
\text { to } \\
\text { Nov. } 26\end{array}$ & $\begin{array}{l}\text { Nov. } 27^{\mathrm{w}} \\
\text { to } \\
\text { Dec. } 10\end{array}$ & $\begin{array}{l}\text { Nov. } 27^{\mathrm{X}} \\
\text { to } \\
\text { Dec. } 10\end{array}$ \\
\hline $0 \mathrm{~S}$ & $614^{\mathrm{d}}$ & $249^{d}$ & $355^{c}$ & $363^{c}$ & $202^{\mathrm{d}}$ & $240^{d}$ & $215^{\mathrm{c}}$ & $220^{c}$ \\
\hline $1 \mathrm{~S}$ & $2239^{c}$ & $829^{c}$ & $1099^{c}$ & $584^{c}$ & $s 00^{c}$ & $593^{c}$ & $684^{c}$ & $590^{c}$ \\
\hline $2 \mathrm{~S}$ & $5144^{\mathrm{b}}$ & $1268^{\mathrm{b}}$ & $2728^{\mathrm{b}}$ & $1153^{\mathrm{b}}$ & $1742^{\mathrm{b}}$ & $1528^{\mathrm{b}}$ & $1100^{\mathrm{b}}$ & $1080^{\mathrm{b}}$ \\
\hline $4 \mathrm{~S}$ & $7906^{\mathbf{a}}$ & $4330^{\mathrm{a}}$ & $3900^{\mathrm{a}}$ & $2043^{\mathrm{a}}$ & $2788^{\mathrm{a}}$ & $2273^{\mathrm{a}}$ & $1750^{\mathrm{a}}$ & $1800^{\mathrm{a}}$ \\
\hline
\end{tabular}

$\mathrm{V}$ : Mean separation in columns by Duncan's multiple range test, $5 \%$ level.

$\mathrm{W}:$ Fruit in main stem. $\mathrm{X}:$ Fruit in lateral shoots.

Table 6. Water soluble $\mathrm{Br}$ in soil fumigated with methyl bromide in relation to time after fumigation ${ }^{\mathrm{W}}$ (ppm of air dried soil).

\begin{tabular}{c|c|c|c|c|c}
\hline \hline Treatment & Oct. $15^{\mathrm{v}}$ & Oct. 29 & Nov. 14 & Nov. 26 & Dec. 10 \\
\hline $0 \mathrm{~S}$ & $6.0^{\mathrm{c}}$ & $6.3^{\mathrm{c}}$ & $5.2^{\mathrm{c}}$ & $5.5^{\mathrm{c}}$ & $4.0^{\mathrm{b}}$ \\
$1 \mathrm{~S}$ & $15.4^{\mathrm{b}}$ & $10.5^{\mathrm{b}}$ & $8.5^{\mathrm{b}}$ & $7.3^{\mathrm{bc}}$ & $4.6^{\mathrm{b}}$ \\
$2 \mathrm{~S}$ & $21.5^{\mathrm{ab}}$ & $13.7^{\mathrm{ab}}$ & $10.4^{\mathrm{ab}}$ & $8.8^{\mathrm{ab}}$ & $6.5^{\mathrm{ab}}$ \\
$4 \mathrm{~S}$ & $28.0^{\mathrm{a}}$ & $17.1^{\mathrm{a}}$ & $13.0^{\mathrm{a}}$ & $10.4^{\mathrm{a}}$ & $8.4^{\mathrm{a}}$ \\
\hline
\end{tabular}

$\mathrm{V}:$ Mean separation in columns by Duncan's multiple range test, $5 \%$ level.

$\mathrm{W}$ : Soil was fumigated on Oct. 11 . 
of $\mathrm{Br}$ in the soil are presented in Table 3,4, 5 and 6. Plant height, dry weight of leaves and stems, and fruit fresh weight were not influenced by $\mathrm{MBr}$ fumigation. $\mathrm{Br}$ uptake by a whole plant was significantly increased with increasing amounts of $\mathrm{MBr}$. At the end of the experiment the amounts at $0,1,2$ and $4 \mathrm{~S}$ were $60,159,244$ and $523 \mathrm{mg}$, respectively.

The $\mathrm{Br}$ content in leaves, stems, roots and fruit was generally increased with increasing amounts of $\mathrm{MBr}$. The content was higher in each plant part taken on Oct. 29, lower in the stems and roots taken on Dec. 10, and lower in the fruit taken between Nov. 27 and Dec. 10. Generally, Br was most concentrated in the stems, less concentrated in the leaves or roots, and least concentrated in the fruit. Water soluble $\mathrm{Br}$ was significantly increased in the soil with increasing amounts of $\mathrm{MBr}$, and gradually decreased in each fumigated soil with time. Eventually the soil $\mathrm{Br}$ content between 0 and $4 \mathrm{~S}$ on Dec. 10 resulted in the least difference- $4.4 \mathrm{ppm}$.

\section{Discussion}

Numerous reports have been published on the effects of soil fumigation with $\mathrm{MBr}$ or other fumigants containing $\mathrm{Br}$ on the growth, yields and $\mathrm{Br}$ uptake in some crops. For instance, Kyrou (7) reported that $\mathrm{MBr}$ at dosages of 40 to 120 liters per $1000 \mathrm{~m}^{2}$ resulted in increased yields of cucumbers by reducing the density of root-knot nematodes. Hayden et al. (4) also reported that preplant $\mathrm{MBr}$ fumigation at dosage of $2 \mathrm{lb}$. per $100 \mathrm{ft}^{2}$ gave a higher growth rate of young peach trees. However, Stelmach (13) found that $\mathrm{MBr}$ at dosage of $370 \mathrm{lb}$. per acre decreased the yields of beans and cabbage due to an excess uptake of inorganic $\mathrm{Br}$ resulting from the hydrosis of this fumigant. In general, favorable effects of $\mathrm{MBr}$ as a soil sterilant on the growth of crops can be attributed to the alleviation of injury from continuous cropping caused by soil-borne diseases and nematodes. In these experiments the growth of cucumbers was not influenced by $\mathrm{MBr}$ fumigation. One of the reasons appears to be attributable to the absence of soil-borne diseases and nematodes due to the use of new paddy soils. The growth of muskmelons was slightly inhibited by the
$3 \mathrm{~S}$ soil $\left(600 \mathrm{~g} / \mathrm{m}^{3}\right)$ treatment. However, the soluble solids of the fruit were slightly higher. As to the phytotoxic effects resulting from the use of $\mathrm{MBr}$, Maw and Kempton (10) reported that the growth inhibition of crops may be caused by (i) the action on plants of the compound per se, (ii) the action of inorganic $\mathrm{Br}$ formed by the breakdown of $\mathrm{MBr}$, or (iii) indirect action through effects of either $\mathrm{MBr}$ or inorganic $\mathrm{Br}$ on soil microflora, soil structure or composition. The growth of muskmelon did not appear to be associated with the above cause (ii), because chlorosis or necrosis caused by an excess of $\mathrm{Br}$ was not found in the leaves. However it was difficult to determine which of the cause (i) or (iii) was responsible for the growth inhibition. The reason that the soluble solids of the fruit were slightly higher at $3 \mathrm{~S}$ soil seemed to be related to the fruit weight because small fruit has generally high soluble solids in greenhouse cultivation.

Inorganic $\mathrm{Br}$ which is present as a breakdown product of $\mathrm{MBr}$ can be taken up and distributed in the tissues of the plants $(6,9$, 13). In our experiments $\mathrm{Br}$ content in the plant parts of muskmelons and cucumbers was significantly increased with increasing amounts of $\mathrm{MBr}$. $\mathrm{Br}$ content in the muskmelon and cucumber leaves at the end of the experiments was high with $6783 \mathrm{ppm}$ at $3 \mathrm{~S}$ and $3638 \mathrm{ppm}$ at $4 \mathrm{~S}$ in Expt. II, respectively. However, there were no characteristic symptoms of phytotoxicity in these plants. This contrasted with the extreme sensitivity of carnations to $\mathrm{Br}$ (5) where the plants showed appreciable leaf damage and growth retardation although $\mathrm{Br}$ content in the leaves of plants grown at 4 S soil $\left(800 \mathrm{~g} / \mathrm{m}^{3}\right)$ was as low as $725 \mathrm{ppm}$.

Some experiments have been made to determine the distribution pattern of $\mathrm{Br}$ taken up in various tissues. For instance, Newton and Toth (11) found higher concentrations of $\mathrm{Br}$ in the stems $(6320 \mathrm{ppm})$, compared with leaflets $(2825 \mathrm{ppm})$ or roots $(2100 \mathrm{ppm})$ in tomato plants grown in nutrient solution containing $20 \mathrm{ppm}$ of inorganic $\mathrm{Br}$. At the end of the experiment with cucumber plants grown at $4 \mathrm{~S}$ soil in Expt. II, $\mathrm{Br}$ was most concentrated in the stems $(13288 \mathrm{ppm})$, less concentrated in the leaves $(3638 \mathrm{ppm})$ and roots $(2043 \mathrm{ppm})$, 
and least concentrated in the fruit (1750 to $1800 \mathrm{ppm})$. This response is similar to the tomato results mentioned above. As to the detailed distribution pattern of $\mathrm{Br}$ in plants, with potatoes (1) less $\mathrm{Br}$ was found in the tubers than in the haulm, and in tubers $\mathrm{Br}$ was concentrated in the skin. Also, with lettuce (6) less than $10 \%$ of the total $\mathrm{Br}$ content of the plant was present in the center portion, representing $25 \%$ of the weight of the plant, and 60 to $85 \%$ of the total $\mathrm{Br}$ was contained in the 12 outermost leaves. In our experiment with muskmelons, $\mathrm{Br}$ was most concentrated in the pericarp (1215 ppm), less concentrated in the outer flesh (323 ppm), and least concentrated in the inner flesh $(228 \mathrm{ppm})$ at $3 \mathrm{~S}$ soil with a similar pattern to the potatoes and lettuce mentioned above.

The composition of soil plays a role in the penetration of $\mathrm{MBr}$. Chisholm and Koblitsky (2) reported that the degree of sorption of $\mathrm{MBr}$ by the soil decreased in the sequence peat $>$ clay $>$ sand. In our cucumber experiments $\mathrm{Br}$ content in the leaves, roots and fruit was markedly higher in Expt. II than in Expt. I. This was probably due to a potential difference in the retention of $\mathrm{MBr}$ between the two soils used in Expt. I and II. That is, Takamatsu light clay in Expt. II had $35.8 \%$ clay, while Iwata loam in Expt. I had only $13.3 \%$ clay. Thus the water soluble $\mathrm{Br}$ at $0,0.5,1$ and $2 \mathrm{~S}$ soils in Expt. I just after the fumigation was $2.5,3.9,5.5$ and $11.6 \mathrm{ppm}$, respectively. In Expt. II that at $0,1,2$ and $4 \mathrm{~S}$ soil was $6.0,15.4,21.5$ and $28.0 \mathrm{ppm}$, respectively.

The uptake extent of $\mathrm{Br}$ into plant tissues is closely related to the amount of inorganic $\mathrm{Br}$ in the soils (6). As shown in Table 3, 4 and $5, \mathrm{Br}$ content in the cucumber plant parts and the uptake amount of $\mathrm{Br}$ by a whole plant reflected well the $\mathrm{Br}$ content of water soluble form in the soil. Br content in the late picked cucumber fruit was higher than that in the early picked one as shown in Table 2. Similar results were reported on young lemon trees by Martin et al. (8).

Accumulation of $\mathrm{Br}$ occurred in muskmelon and cucumber fruit to a substantially lesser extent than in leaves. Muskmelon fruit on the plants grown in soil fumigated with 600 $\mathrm{g} / \mathrm{m}^{3} \mathrm{MBr}$, which is a higher dosage but of ten being used by greenhouse growers, contained $228 \mathrm{ppm}$ of dried tissue (23 ppm of fresh tissue) in the inner flesh and $323 \mathrm{ppm}(32 \mathrm{ppm})$ in the outer flesh. Cucumber fruit on the plants grown in soil fumigated with 200 and $400 \mathrm{~g} / \mathrm{m}^{3}$ $\mathrm{MBr}$ in Expt. II contained 590 to $900 \mathrm{ppm}$ of dried tissue ( 30 to $45 \mathrm{ppm}$ of fresh tissue) and 1080 to $1742 \mathrm{ppm}$ of dried tissue (54 to $87 \mathrm{ppm}$ ), respectively. Although there are no statutory limits on the $\mathrm{Br}$ content of foodstuffs in Japan except for cereal grains, maximum levels for $\mathrm{Br}$ in a range of foodstuffs have been proposed by the FAO Codex Committee on Pesticide Residues (FAO/WHO), including suggested limits of 20 to $30 \mathrm{ppm}$ for various fresh fruits and 30 to $250 \mathrm{ppm}$ for dried fruits. Also, in the U.S.A. tolerances for $\mathrm{Br}$ residues in plants grown in soil treated with various nematocides have been established by the FDA (14). These values are $75 \mathrm{ppm}$ for melons and 50 ppm for cucumbers on a fresh weight basis. In a comparison of $\mathrm{Br}$ content in the muskmelon and cucumber fruit obtained by the authors with those by the FDA, $\mathrm{Br}$ in the muskmelon fruit was within the tolerance limit even in the soil fumigated with $600 \mathrm{~g} / \mathrm{m}^{3}$ $\mathrm{MBr}$, while $\mathrm{Br}$ in the cucumber fruit was beyond the tolerance limit in the soil fumigated with $400 \mathrm{~g} / \mathrm{m}^{3} \mathrm{MBr}$. When we consume $200 \mathrm{~g}$ of cucumber fruit containing $50 \mathrm{ppm} \mathrm{Br}$ on a fresh weight basis, then $\mathrm{Br}$ intake by the human body will be $10 \mathrm{mg}$. This is substantially low compared with a maximum acceptable daily intake of $60 \mathrm{mg} \mathrm{Br}$ ion for $60 \mathrm{Kg}$ body weight recommended by a joint party $\mathrm{FAO} / \mathrm{WHO}$. Thus $\mathrm{Br}$ content in the cucumber fruit of plants grown in soil fumigated with $400 \mathrm{~g} / \mathrm{m}^{3} \mathrm{MBr}$ was beyond the tolerance limit established by the FDA. However, this level of $\mathrm{Br}$ appeared to be safe judging from the acceptable limit of daily intake of $\mathrm{Br}$ recommended by $\mathrm{FAO} / \mathrm{WHO}$.

Since $\mathrm{MBr}$ is being used on an increasing scale in Japan to fumigate soil beds for greenhouse crop production, it must be recognized that the harvest fruit or edible part will contain small quantities of $\mathrm{Br}$. At the same time probably more attention needs to be given to lar components of the diet as Maw and Kempton (10) pointed out. 


\section{Literature Cited}

1. Brown, G., C.M. Corbett, G.A. Hide, and R. M. WEBB. 1974. Bromine residues in potato and wheat crops grown in soil fumigated with methyl bromide. Pestic. Sci. $5: 25-29$.

2. Chisholm, R. D., and L. Koblitsky. 1943. Sorption of methyl bromide by soil in a fumigation chamber. J. Econ. Ent. $36: 549$ 551.

3. FAO/WHO. 1970. Pesticide residues in food. Report of the 1969 Joint Meeting of the FAO Working Party of Experts on Pesticide Residues and the WHO Expert Group on Pesticide Residues. Rome. 8-15. Dec. Tech. Rep. Ser. No. 458.

4. Hayden, R. A., E. F. Savage, and V. E. PRINCE. 1968. Growth of young peach trees as affected by preplant fumigant treatments. Proc. Amer. Soc. Hort. Sci. 93 : 119-127.

5. ISHIDA, A., M. MASUI, and T. OgurA. 1975. Bromine study of carnations. I. Bromine injury caused by methyl bromide as a soil fumigant. Abstracts. 1975 Fall Meeting Japan. Soc. Hort. Sci. 469.

6. Kempton, R. J., and G. A. MAw. 1972. Soil fumigation with methyl bromide: Bromide accumulation by lettuce plants. Ann. Appl. Biol. $72: 71-79$.

7. KYROU, N.C. 1973. Soil treatments for control of root-knot nematodes (Meloidogyne incongnita) in greenhouse-grown cucumber.
Plant Dis. Reptr. 52 : 1032-1033.

8. MARTIN, J.P., D. G. ALDRICH, W.S. MURPHY, and G. R. BRADFORD. 1953. Effect of soil fumigation on growth and chemical composition of citrus plants. Soil Sci. 75 : 137151.

9. - G. K. HelmKAMP, and J. O. ERVIN. 1956. Effect of bromide from a soil fumigant and $\mathrm{CaBr}_{2}$ on growth and chemical composition of citrus plants. Soil. Sci. Soc. Amer. Proc. 20 : 209-212.

10. MAw, G. A., and R. J. Kempton. 1973. Methyl bromide as a soil fumigant. Soils and Fertilizers $36: 41-47$.

11. Newton, H.P., and S.J. Toth. 1952. Response of crop plants to I and Br. Soil Sci. $73: 127-134$.

12. SNEll, F.D., and C.T. SNELl. 1957. Colorimetric methods of analysis. P. 725. D. Van Nostrand. New York.

13. STELMACH, Z. 1959. Bromine retention in some soils and uptake of bromine by plants. after soil fumigation. Soil Sci. $88: 61-66$.

14. TAYLOR, A.L. 1963. Nematocide residues in plants. Residues Reviews $2: 1-8$.

15. U.S. A. ENVIRONMENT PROTECTION AGENCY. 1972. Tolerances and exemptions from tolerances for pesticide chemicals in or on raw agricultural commodities. Federal Register. 37 (208) : 22983.

16. 1972. Ditto. Ibid. 37 (221) : 24183.

\title{
臭化メチルの土壤くん蒸消毒がメロンとキュウリの 臭素吸収に及ぼす影響
}

\author{
増井正夫・糠谷 明 - 小倉孝保 - 石田 明 \\ (静岡大学農学部)
}

\begin{abstract}
摘
臭化メチル $(\mathrm{MBr})$ の土壤くん蒸消毒が，メロンとキ ニウリの生育, 植物体と土壤の臭素 $(\mathrm{Br})$ 含量に及ぼす 影響を明らかにするため, これら両野菜を栽培した。メ ロンの全乾物重は, $\mathrm{MBr} 600 \mathrm{~g} / \mathrm{m}^{3}$ で少なくなったが, 果実の可溶性固形物含量はやや高かった.メロンの葉の $\mathrm{Br}$ 含量は, $\mathrm{MBr} 0,200,400,600 \mathrm{~g} / \mathrm{m}^{3}$ で，それぞれ 203，540，3663，6783ppm であった. メロンの果実の $\mathrm{Br}$ 含量は, 果皮が最も高く, 果肉外壁部がこれに次ぎ, 果肉内壁部が最も低かった. 果肉の $\mathrm{Br}$ 含量を乾物重当 たりでみると，MBr 0，200，400，600 g/ $/ \mathrm{m}^{3}$ の内壁部

では，それぞれ 47，24，109，228 ppm であり，外壁部

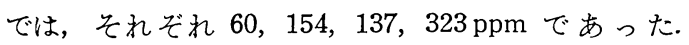
13.3\% の粘土を含む磐田壤土で栽培したキュウリの生 育, 收量は, $\mathrm{MBr}$ の使用量によって影響されな かった. しかし, 葉, 根, 果実の $\mathrm{Br}$ 含量は, $\mathrm{MBr}$ の 使用量の増加とともに高まった. $35.8 \%$ の粘土を含む 高松軽埴土で栽培したキュウリの生育, 収量は, $\mathrm{MBr}$ の使用量によって影響されなかった. 乾物重当たりの 葉, 根, 果実の $\mathrm{Br}$ 含量は, 磐田壤土よりも高松軽埴土 で著しく高く, $\mathrm{MBr} 0,200,400,800 \mathrm{~g} / \mathrm{m}^{3}$ における
\end{abstract}


高松軽埴土の果実の $\mathrm{Br}$ 含量は，それぞれ 202-240，590 -900，1080-1742，1750-2788 ppm であった. キュウリ
の $\mathrm{Br}$ 吸収量は, $\mathrm{MBr}$ のどの使用量区でも時間の経過 とともに増加したが, 土壤の $\mathrm{Br}$ 含量は逆に減少した. 